\title{
Evaluation of the Efficacy of CGA 245704 Combined or Not with CGA 329351 (Mefenoxam) for the Control of Tobacco Blue Mold (Peronospora tabacina) : Results of Four Years of Experiments*
}

\author{
by \\ René Delon, Bernard Cailleteau, Jean Louis Verrier, \\ Seita, Institut du tabac, \\ 24100 Bergerac, France \\ Marie Noëlle Tanne and Michel Sylvestre \\ Novartis Agro S.A., \\ 92845 Rueil Malmaison, France
}

\section{SUMMARY}

A compound for activating systemic resistance (CGA $245704)$, in the chemical class of benzothiadiazoles, was studied since 1993 for the control of tobacco blue mold (Peronospora tabacina A.) in seedbeds and in the field. One foliar application of CGA 245704 at $1.6 \mathrm{~g}$ active ingredient/hl every 14 days protected tobacco plants against blue mold but protection was not total. Mixed with mefenoxam (CGA 329 351) at $16 \mathrm{~g}$ active ingredient/ $\mathrm{hl}$ the protection is equivalent to standard Acylon ${ }^{\circledR}$ TC $(25 \%$ metalaxyl, $50 \%$ maneb) applied as foliar spray at $0.160 \mathrm{~kg} / \mathrm{hl}(40 \mathrm{~g}$ active ingredient metalaxyl per $\mathrm{hl}$ ). This allows a reduction in the quantity of fungicides dispersed in the environment and the pesticide residues on the tobacco leaves. At the rate applied, no phytotoxic effects were observed in seedbeds or in the field.

\section{ZUSAMMENFASSUNG}

Seit 1993 wird ein Aktivator für die natürlichen Abwehrmechanismen der Pflanzen (CGA 245 704), der zur Familie der Benzothiadiazole gehört, zur Bekämpfung des Blauschimmels des Tabaks (Peronospora tabacina $\mathrm{A}$.)

* Received: 15th April 1998 - accepted: 13th July 1998

in Saatbeeten und im Freiland erprobt. Ein Auftragen von $1,6 \mathrm{~g} / \mathrm{hl}$ Aktivsubstanz (AS) auf die Blätter in einem zweiwöchigen Intervall schützte die Tabakpflanzen vor Blauschimmelbefall; dieser Schutz war jedoch nicht vollständig. Wurde die Wirksubstanz (CGA 245 704) mit $16 \mathrm{~g}$ AS/hl Mefenoxam (CGA 329 351) gemischt, entsprach der Schutz vor Blauschimmel demjenigen Schutz nach Auftragen der Standardsubstanz Acylon ${ }^{\circledR}$ TC (25\% Metalaxyl, $50 \%$ Maneb) in einer Konzentration von $0,160 \mathrm{~kg} / \mathrm{hl}$ (entsprechend einer Menge von $40 \mathrm{~g}$ AS Metalaxyl pro hl). Auf diese Weise lassen sich die Fungizidmengen in der Umwelt und die Pestizidrückstände auf den Tabakblättern verringern. Bei den verwendeten Konzentrationen wurde weder in den Saatbeeten noch im Freiland Phytotoxizität beobachtet.

\section{RESUME}

Depuis 1993, un stimulateur des défenses naturelles des plantes (CGA 245 704) appartenant à la famille des benzothiadiazoles est expérimenté dans la lutte contre le mildiou du tabac (Peronospora tabacina A.) en pépinière et en plein champ. Une application de CGA 245704 à $1,6 \mathrm{~g}$ matière active (m.a.)/hl tous les 14 jours assure une protection à l'égard $\mathrm{du}$ mildiou sans toutefois être totale. Associée au méfenoxam (CGA 329 351) à $16 \mathrm{~g}$ m.a./hl, la protec 
tion est équivalente à celle obtenue avec le produit de référence Acylon ${ }^{\circledR}$ TC $(25 \%$ métalaxyl, $50 \%$ manèbe) appliqué à $0,160 \mathrm{~kg} / \mathrm{hl}$ (soit $40 \mathrm{~g}$ de métalaxyl/hl) ce qui permet de réduire les quantités de produits phytosanitaires appliquées dans l'environnement et les résidus sur la matière première. Aux doses employées, aucun phénomène de phytotoxicité, tant en pépinière qu'au champ n'a été observé.

\section{INTRODUCTION}

In France, the combination of metalaxyl and maneb, used under the commercial name of Acylon ${ }^{\circledR}$ TC and applied as a foliar spray at $0.160 \mathrm{~kg} / \mathrm{hl}$, has been used routinely in seedbeds and in the field for the control of tobacco blue mold (P. tabacina) since 1981 (5). Until now, no selection for resistance to phenylamides has been observed in France or in Europe. However, because of environmental and residue concerns about the use of dithiocarbamates, phytosanitary companies seek alternative products which are equally effective but result in lower residues. Since 1993 the Bergerac Tobacco Institute (SEITA) has studied the efficacy of new compounds developed by Novartis. Amongst these are a stimulator of the natural defense system of plants (CGA 245 704) and the most active enantiomer of metalaxyl, called mefenoxam (commercial name Tega ${ }^{\circledR}$ Bion ${ }^{\circledR}$ ) or CGA 329 351. The results of these four years of experiments are very promising (1-6).

\section{MATERIALS AND METHODS}

The experiments were carried out at the Bergerac Tobacco Institute, SEITA, Bergerac, France, according to good experimental practice (G.E.P). Experiments were carried out both in the seedbed and in the field so as to evaluate the selectivity and efficacy of CGA 245704 alone and in combination with mefenoxam (CGA 329 351).

\section{The chemicals studied}

CGA 245704 is a plant activator which activates the plant's natural defense mechanism referred to as "systemic activated resistance" (SAR). It has the commercial name Actigard $^{\circledR}$ (WG 50) and was developed by Novartis Agro in the U.S.A. The active product is acibenzolar-S-methyl, a member of the family of benzothiadiazoles. The commercial form which dissolves in water contains $50 \%$ active material CGA 245704 (WG 50).

- MO 751 or M 3925 (WG 42) formula contains 2 \% of CGA 245704 and $40 \%$ of metalaxyl.
- $\quad$ MO 752 or M 3935 (WG 44) formula contains 4 \% of CGA 245704 and $40 \%$ of CGA 329351 (Tega ${ }^{\circledR}$ Bion $\left.^{\circledR}\right)$. CGA 329351 or mefenoxam is the R-enantiomer of metalaxyl.

- Acylon ${ }^{\circledR}$ TC (25\% metalaxyl and $50 \%$ maneb) is the standard product registered in France on tobacco at $0.160 \mathrm{~kg}$ commercial product (c.p.) $/ \mathrm{hl}$ ( $40 \mathrm{~g}$ of metalaxyl and $80 \mathrm{~g}$ of maneb/hl) every 14 days.

\section{Trials to test effects of CGA 245704 on tobacco}

The purpose of these studies was to evaluate the effects produced on growth, depigmentation, weight of production, quality of the raw material and other alterations to plants treated in relation to the untreated control and a reference product.

\subsection{In the seedlings (1995 and 1996)}

In 1995, experiments were carried out in the greenhouse to determine the effects of CGA 245704 on young plants (Virginia ITB 32) from 19 to 60 days after transplanting into mini cells ( 80 plants per tray) on a wet carpet and irrigated by spraying. Treatments were carried out with a volume equivalent to 1000 $1 /$ ha with the aid of an aerosol spray under 2.5 bars pressure.

In 1996, experiments were carried out on three varieties (dark air-cured) ITB 1000, (flue-cured) ITB 32 and (burley) BB16 A in traditional outdoor seedbeds.

After sowing dry seed and covering it with a plastic film, treatments were carried out at the true two leaf stage at a rate of $1000 \mathrm{l} / \mathrm{ha}$ with the aid of a mechanical sprayer under 1 bar of pressure. Seedlings were observed until transplanting.

\subsection{In the field}

During 1994, a selectivity study was carried out in the field on six varieties of tobacco : (dark air-cured ) ITB 1000 and PB D6, (flue-cured) Virgin SCR and ITB 32, and (burley) BB16 and BB16 A, cultivated under the recommended conditions for the different types of tobacco. The products MO 751 or M 3925 (WG 42) were applied by foliar sprays at 2 doses : $1.25+25$ every 7 days and $2.5+50$ g c. p. $/$ hl every 14 days. Experiments were carried out in the form of randomized plots with two replications. Each elementary plot comprised 24 plants.

Selectivity was determined by comparing the yield, the quality index and some of the chemical characteristics of the raw material after harvesting and curing, total alkaloids, nitrogen content, reducing sugars (flue-cured) and nitrate content (dark air-cured and burley). 


\section{Efficacy trials}

\subsection{In the seedlings (1996)}

The experiment was carried out in the greenhouse. Young plants (flue-cured cv. ITB 32) were transplanted at the cotyledon stage into mini cells in polystyrene trays. The seedlings were grown by the " float system". The trial comprised 4 treatments and 2 replications (Fisher's blocks). There were four treatments, including an untreated control, the reference product Acylon ${ }^{\circledR}$ TC $(160$ g c.p./hl) and two doses of M 3935 (30 and $40 \mathrm{~g}$ c.p./hl). Each plot consisted of a tray of 84 plants. Treatments were applied as foliar sprays at $1000 \mathrm{l} /$ ha and a pressure of 2.5 bars.

Following two treatments in the greenhouse, the trays were removed to a growth room with controlled temperature and humidity. The seedlings were inoculated with a suspension of conidia (100 000 sporangia $/ \mathrm{ml}$ ) from the strain of $P$. tabacina maintained at the Bergerac Tobacco Institute.

Disease ratings for blue mold were made on each plant in each plot (tray) based on a scale $0-5$, where $0=$ total absence of blue mold and $5=$ more than 50 $\%$ of the foliar surface attacked.

\subsection{In the field (1995, 1996 and 1997)}

Field experiments were conducted as randomized complete block design with 4 replicates. Each plot comprised 30 viable treated plants (susceptible variety), bordered by a row of untreated plants which were used to trap blue mold as protection from the adjacent treatments. Treatments were carried out with a sprayer under constant pressure (3 bars) equipped with a spray line having turbulent jets. To facilitate natural infection by tobacco blue mold and to reduce interference with neighboring tests, the cultures were transplanted later than usual ( 1 or 2 months in relation to traditional crop). Blue mold ratings were carried out on each plant in each plot according to a scale of $0-9(0=$ total absence of blue mold, $9=$ more than 50 spots per plant or more than $25 \%$ of the foliar surface attacked)

\section{Study of the systemic action of CGA 245704}

This study was carried out to determine the efficacy of CGA 245704 applied to the water in the troughs of the "float system". The experimental design was identical to that described for the seedbed study. CGA 245704 was applied at two rates 0.1 and 0.15 mg c.p./plant given that each tray contained 80 tobacco plants and a liquid capacity of 101 solution, and compared with an untreated control.

After 25 days of root contact with the product, the trays were removed from the greenhouse and moved to a growth room with controlled temperature and humidity. The young plants were inoculated with 3 $\mathrm{ml} /$ plant of a suspension of conidia (100 000 sporangia $/ \mathrm{ml}$ ) of a strain of P. tabacina maintained at the Bergerac Tobacco Institute.

Blue mold ratings were made on each plant of each plot (tray) on a scale of $0-5$ described above.

\section{RESULTS}

\section{Test of effects on tobacco}

\subsection{Evaluation of the seedlings (1995 and 1996)}

- 1995 : Seedlings sprayed with CGA 245704 (WG 50) at 1.2 and $1.6 \mathrm{~g}$ c.p/hl. every 7 days and at 2.4 g c.p./hl every 14 days showed no alteration in the development of leaves whatever the dose and rate of treatment. Plants sprayed every 7 days received 5 applications, and those sprayed every 2 weeks received 3 applications. During the experiment the temperatures under cover varied from 0 to $30^{\circ} \mathrm{C}$ and the soil temperatures varied from 8 to $19^{\circ} \mathrm{C}$. The formulation of CGA 245 704 and mefenoxam (WG 44), applied at a rate of 20 to $30 \mathrm{~g} / \mathrm{hl}$ every 14 days also showed no phytotoxic effects on the young plants in the seedbed.

- 1996 : The product CGA 245704 (WG 50), applied every 14 days at a rate of 3.2 and $4.8 \mathrm{~g} / \mathrm{hl}$, and the formulation CGA $245 \quad 704$ and mefenoxam (WG 44) at 40 and $60 \mathrm{~g} / \mathrm{hl}$, double the dose applied in 1995, did not provoke any alteration or deformation of tobacco seedlings when temperatures under cover varied from $5^{\circ} \mathrm{C}$ to $40^{\circ} \mathrm{C}$.

\subsection{Field evaluation (1994, Bergerac)}

In the field study when tobacco received 5 to 9 foliar applications of MO 751 or M 3925 (WG 42) at two rates $(1.25+25$ and $2.5+50$ g c.p. $/ \mathrm{hl})$, there was no or very little influence on the yield in weight of the six varieties (Figure 1).

Slightly stimulatory effects on yield were even noted at the lowest dose for most varieties. As concerns the quality index by the Seita experts (Figure 2), the use of a mixture of M 3925 shows no significant modification at the level of doses studied. No significant variation of chemical character 


\begin{tabular}{lcccc}
\hline \multicolumn{1}{c|}{ Treatments } & $\begin{array}{c}\text { Rate in } \\
\text { active ingredient/hl }\end{array}$ & Commercial product & $\begin{array}{c}\text { Rating scale } \\
(0-5)\end{array}$ \\
\hline Untreated check & - & - & $5 \mathrm{a}^{*}$ \\
Acylon® TC (metalaxyl + maneb) & $40+80$ & 160 & $0 \mathrm{~b}$ \\
CGA 245 704 + mefenoxam & $1.2+12$ & 30 & $0 \mathrm{~b}$ \\
CGA 245 704 + mefenoxam & $1.6+16$ & 40 & $0 \mathrm{~b}$ \\
\hline
\end{tabular}

* Means followed by the same letter are not significantly different $(P=0.05)$ according to the NEWMAN-KEULS test.

istics in the raw material analyzed after harvesting and drying was observed as regards : total alkaloids, total nitrogen content, reducing sugars (flue-cured), and nitrates (dark air-cured and burley).

\section{Study of the efficacy against P. tabacina}

\subsection{Control of blue mold in the seedlings}

In the greenhouse experiments, there was good protection of seedlings (flue-cured cv. ITB 32) following foliar applications of Acylon ${ }^{\circledR}$ TC or M 3935 every 14 days.
Only untreated plants developed symptoms of the disease after inoculation under controlled conditions with a strain of blue mold. In relation to the reference Acylon ${ }^{\circledR}$ TC (160 g c.p./hl), no difference has been observed for the product M 3935 or Tega ${ }^{\circledR}$ Bion ${ }^{\circledR}$, containing $4 \%$ CGA 245704 and $40 \%$ CGA 329351 either at 30 or 40 g c.p./hl (Table 1).

\subsection{Performance in the field}

- 1993 and 1994 : The absence of blue mold prevented field evaluation of the efficacy of the experimental products.

Table 2 .

Evaluation of the efficacy of CGA 245704 alone or in combination with mefenoxam or metalaxyl for the blue mold control in the field at Bergerac, France, 1995.

\begin{tabular}{l|c|c|c}
\hline \multicolumn{1}{c|}{ Treatments } & g/ commercial product / hl & $\begin{array}{c}\text { Spray } \\
\text { interval }\end{array}$ & $\begin{array}{c}\text { Rating scale } \\
(0-9)\end{array}$ \\
\hline Untreated check & 160 & - & $2.1 \mathrm{a}^{*}$ \\
Acylon® TC & 1.6 & 14 & $0 \mathrm{~b}$ \\
CGA 245 704 & 2.4 & 7 & $0 \mathrm{~b}$ \\
CGA 245 704 & 20 & 14 & $0 \mathrm{~b}$ \\
MO 752 & 30 & 14 & $0 \mathrm{~b}$ \\
MO 752 & 60 & 14 & $0 \mathrm{~b}$ \\
MO 751 & 14 & $0 \mathrm{~b}$ \\
\hline
\end{tabular}

* Means followed by the same letter are not significantly different (P: 0.05) according to the NEWMAN-KEULS test. 


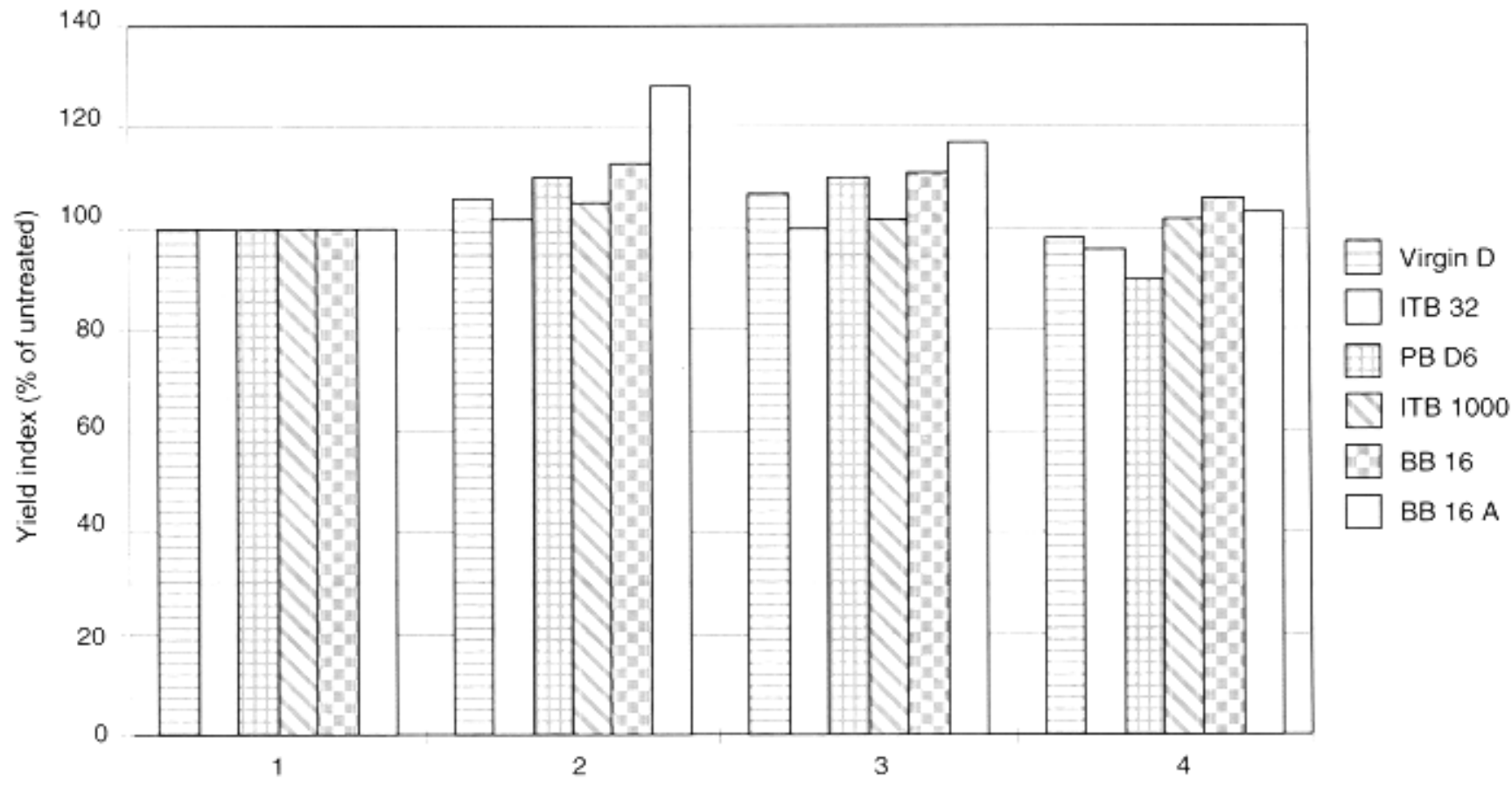

Figure 1.

Influence of foliar spraying of M3925 (CGA 245704 combined with metalaxyl) on the weight of yield in

six varieties $(1$ = untreated control; 2 = reference Acylon $\odot$ TC $160 \mathrm{~g} / \mathrm{hl}$ with 5 applications; $3=\mathrm{M} 3925$ at $1.25+$ $25 \mathrm{~g} / \mathrm{hl}$ with 9 applications; $4=\mathrm{M} 3925$ at $2.5+50 \mathrm{~g} / \mathrm{hl}$ with 5 applications).

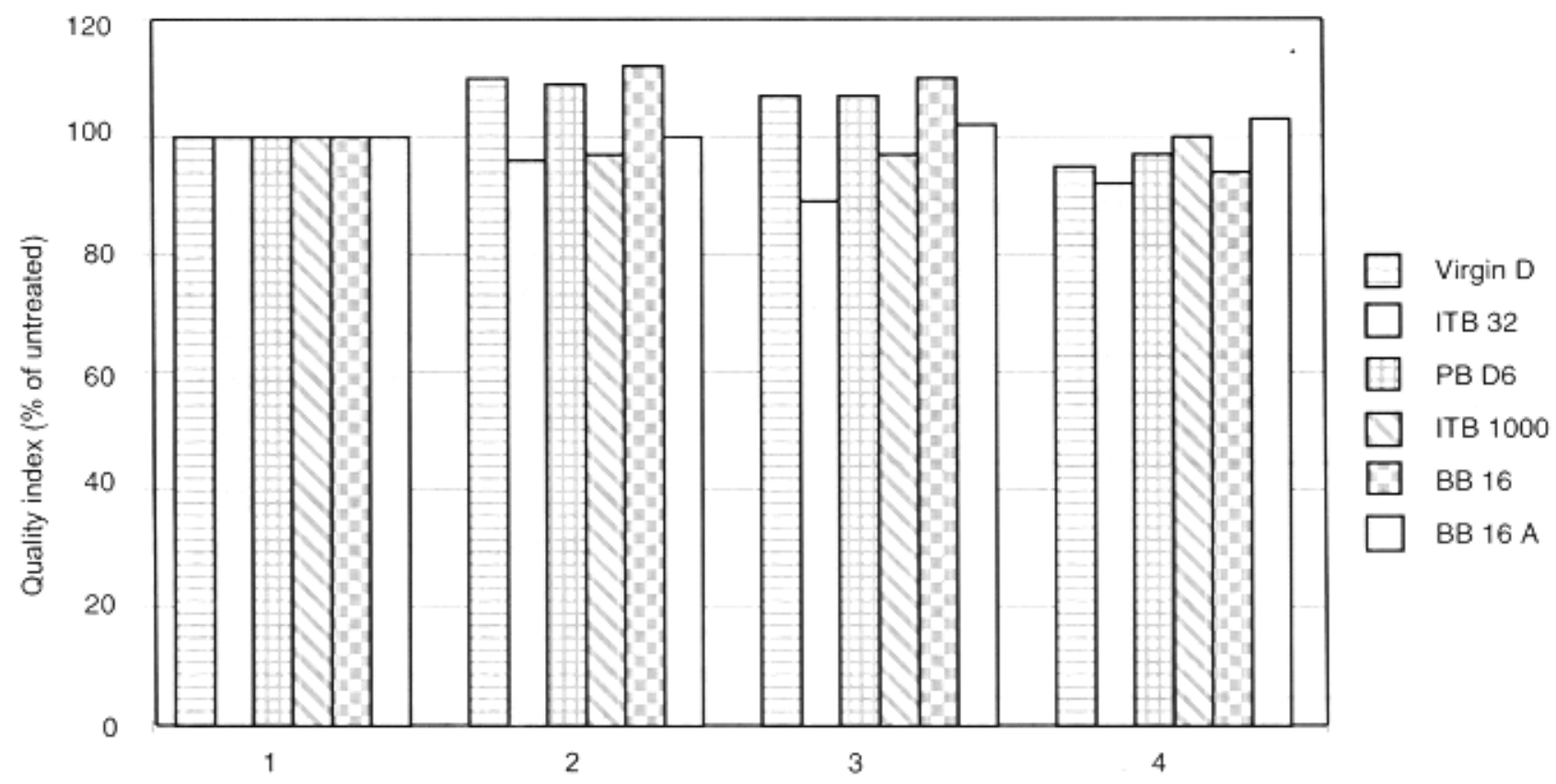

Figure 2,

Influence of foliar spraying of M3925 (CGA 245704 combined with metalaxyl) on the quality index of six varieties ( 1 = untreated control; 2 = reference Acylone TC $160 \mathrm{~g} / \mathrm{hl}) ; 3=\mathrm{M} 3925$ at $1.25+25 \mathrm{~g} / \mathrm{hl} ; 4=\mathrm{M} 3925$ at $2.5+50 \mathrm{~g} / \mathrm{hl})$. 
Table 3.

Evaluation of the efficacy in the field of CGA 245704 alone or in combination with mefenoxam for P. tabacina, at Bergerac, France, 1996 (variety: ITB 32).

\begin{tabular}{lc|c|c|c}
\hline Treatments & $\begin{array}{c}\text { g/ commercial } \\
\text { product / hl }\end{array}$ & $\begin{array}{c}\text { Number of } \\
\text { treatments }\end{array}$ & $\begin{array}{c}\text { Disease score } \\
15 \text { days after the } \\
\text { last treatment }\end{array}$ & $\begin{array}{c}\text { Disease score } \\
21 \text { days after the } \\
\text { last treatment }\end{array}$ \\
\hline Untreated check & & 0 & $7.7 \mathrm{a}^{*}$ & $8.6 \mathrm{a}^{*}$ \\
Acylon® TC (reference) & 160 & 4 & $0 \mathrm{c}$ & $0 \mathrm{c}$ \\
CGA 245704 & 2.4 & 4 & $4.2 \mathrm{~b}$ & $6 \mathrm{~b}$ \\
CGA 245704 & 3.2 & 4 & $2.6 \mathrm{bc}$ & $5 \mathrm{~b}$ \\
MO 752 & 30 & 4 & $0 \mathrm{c}$ & $0 \mathrm{c}$ \\
MO 752 & 40 & 4 & $0 \mathrm{c}$ & $0 \mathrm{c}$ \\
\hline
\end{tabular}

* Means followed by the same letter are not significantly different $(P=0.05)$ according to the NEWMAN-KEULS test.

Table 4 .

Comparison of a mixture of CGA 245704 and mefenoxam (WG 44) with Acylon ${ }^{\circledR}$ TC for $P$. tabacina in the field at Bergerac, France, 1997 (variety: ITB 3304).

\begin{tabular}{l|c|c|c}
\hline Treatments & $\begin{array}{c}\text { Rate in g / commercial } \\
\text { product / hl }\end{array}$ & $\begin{array}{c}\text { Disease score } \\
(0-9)\end{array}$ & \% Attacked plants \\
\hline Untreated check & - & $8.4 \mathrm{a}^{*}$ & 100 \\
Acylon TC $\circledast$ (reference) & 160 & $0 \mathrm{~b}$ & 0 \\
MO 752 & 40 & $0 \mathrm{~b}$ & 0 \\
\hline
\end{tabular}

* Means followed by the same letter are not significantly different $(P=0.05)$ according to the NEWMAN-KEULS test.

Table 5.

Efficacy of CGA 245704 applied to the float water for protection against tobacco blue mold.

\begin{tabular}{l|c|c}
\hline \multicolumn{1}{c|}{ Treatments } & $\begin{array}{c}\text { mg / commercial } \\
\text { product / plant }\end{array}$ & $\begin{array}{c}\text { Disease } \\
\text { score } \\
(-5)\end{array}$ \\
\hline Untreated check & 0 & $5 \mathrm{a}^{*}$ \\
Acylon® TC & 5 & $0 \mathrm{c}$ \\
CGA 245704 & 0.1 & $1.15 \mathrm{~b}$ \\
CGA 245704 & 0.15 & $0.01 \mathrm{c}$ \\
\hline
\end{tabular}

* Means followed by the same letter are not significantly different $(P=0.05)$ according to the NEWMAN-KEULS test.

- In 1995, the field trial was carried out with the dark air-cured variety Paraguay 48, susceptible to tobacco blue mold. A weak attack prevented distinguishing different levels, and only the untreated control showed some spots of blue mold. No attack was observed on the plants treated with either CGA 245 704 at $1.6 \mathrm{~g} / \mathrm{hl}$ every 7 days or $2.4 \mathrm{~g} / \mathrm{hl}$ every 14 days, and on the plants with the reference Acylon ${ }^{\circledR} \mathrm{TC}$ at $160 \mathrm{~g} / \mathrm{hl}$ every 14 days (Table 2).

During 1996, the tobacco blue mold outbreak was experimentally favored by mist spraying the trial tobacco and by transplantation at the end of the growing season, which allowed verification of the efficacy of different types of treatments (Table 3). The product CGA 245704 used alone at 2.4 or $3.2 \mathrm{~g}$ c.p./hl every 14 days was effective but did not entirely protect the plants from blue mold. By mixing with mefenoxam, the protection is equivalent to that of the reference product Acylon ${ }^{\circledR} \mathrm{TC}$, and both the 30 and $40 \mathrm{~g}$ dosage provide complete protection.

In 1997, as in 1996, blue mold was experimentally promoted by mist spraying in the late trial. Blue mold 
appeared in the trial on August 21 after a second treatment. A first reading took place on September 12. The control had $100 \%$ of the plants affected by blue mold and abundant sporulation. The two treatments spayed with Acylon ${ }^{\circledR}$ TC (reference) and the new formulation M 3935 (4\% of CGA 245704 and $40 \%$ of CGA 349351 or mefenoxam) showed no blue mold symptoms (Table 4).

The results obtained in the field during the past three years show that preventive foliar sprays with CGA 245704 and mefenoxam are as effective for blue mold control as the reference product Acylon ${ }^{\circledR} \mathrm{TC}$. Under conditions favorable for blue mold CGA 245704 alone did not provide complete protection against blue mold.

\section{Study of the systemic activity of CGA 245704}

The introduction of CGA 245704 into the float water of the "Float System" protects seedlings following inoculation with P. tabacina (Table 5). However, this protection was not complete even at the highest dose $0.15 \mathrm{mg}$ c.p/plant (12 mg c.p./80 plants or 101 of solution).

\section{CONCLUSION}

The trials carried out at Bergerac since 1993 with CGA 245 704, an inducer of the natural biological phenomenon termed "systemic activated resistance" (SAR), showed that this substance when applied preventively by foliar spraying at $1.6 \mathrm{~g}$ active ingredient/hl every 14 days induces a protection against tobacco blue mold. However, protection it is not total and depends on the severity of the epidemic conditions.

CGA 245704 placed into the nutritive solution of the "float system" for seedlings production provides protection of the aerial parts of the young plants. This confirms the systemic nature of the defense reaction of the plant (3), but as in the foliar application protection is only partial. However, CGA 245 704 stimulates the natural defense of the plant and can also have an effect on other pathogens of tobacco such as $P$. syringae $c v$. tabaci (1) which broadens the spectrum of activity of this substance. This product is therefore, by its systemic action, polyvalent and leaves no residue, constituting an excellent replacement for maneb or mancozeb.

CGA 245704 combined with mefenoxam did not produce phytotoxicity at the rates and doses used. However, phytotoxicity with CGA 245704 on burley has been reported in the USA (6).

As we have seen at Bergerac in 1995, 1996 and 1997, this mixture used preventively in foliar sprays every 14 days at a dose of 30 or $40 \mathrm{~g}$ of c.p. Tega ${ }^{\circledR}$ Bion $^{\circledR}$ per hl provides an excellent protection, equivalent to that obtained with the reference product Acylon ${ }^{\circledR}$ TC at $160 \mathrm{~g} / \mathrm{hl}$, every 14 days, at the seedbed stage as well as in the field. In Italy similar results have been obtained (3).

CGA 245704 combined with mefenoxam offers an additional approach for effectively controlling the disease while reducing the quantities of fungicides used in tobacco growing countries where tobacco blue mold represents a major risk, and in the absence of strains resistant to metalaxyl.

The use of substances which stimulate the natural defense system systemically and for a range of pathogens is an advantageous alternative to maneb or mancozeb.

However, as has been shown in France since 1980 (4), monitoring the appearance of strains of $P$. tabacina resistant to metalaxyl should continue to be carried out in order to conserve, for the longest time possible, the efficacy of metalaxyl and products of the family of the phenylamides against blue mold in tobacco. In Europe, the level of efficacy of metalaxyl has stayed constant for more than 17 years, which is not the case in Central America or North America.

\section{Acknowledgments}

The authors wish to thank in particular Mme Francoise Paludetto and Mme Brigitte Mazeau, Tobacco Institute, Seita, Bergerac, for their efficient contribution to carrying out these trials and Prof. P.B. Shoemaker for reviewing the manuscript.

\section{REFERENCES}

1. Cole, D.L.: Evaluation of a plant activator (CGA $245704)$ to induce systemic acquired resistance in tobacco; Paper presented at the occasion of the CORESTA Congress, Yokohama, Japan 3-8 November 1996, Information Bulletin, p. 155.

2. Kessmann, H., M. Oostendorp, W. Ruess, T.Staub, W. Kunz and J. Ryals: Systemic activated resistance: a new technology for plant disease control; Pesticide Outlook, June 1996.

3. Ruess, W., K. Mueller, G. Knaufbeiter, W. Kunz and T. Staub: Plant activator CGA 245704: an innovative approach for disease control in cereals and tobacco. Paper presented at the occasion of the British Crop Protection Council, Brigthon, UK, 19-21 November 1996.

4. Delon R. and P. Schiltz: Etude du mode d'action exercée par le métalaxyl sur Peronospora tabacina. III Surveillance, en 1980, de l'activité du métalaxyl sur quelques isolats de mildiou du tabac: "le test cotylédon-monitoring"; Annales du Tabac 17, Section 2 (1981-82) 59-64. 
5. Schiltz, P., R. Delon, F. Cazamajour, G. Podeur et R. Boulogne: Comparaison de quelques fongistatiques et de produits endothérapiques pour la lutte contre le mildiou du Tabac; Annales du Tabac 14, Section 2 (1977) 127-154.

6. Shoemaker, P.B. et C.E. Main: Experimental results with Actigard (CGA 245704) for blue mold in North Carolina,U.S.A; Paper presented at the occasion of the CORESTA Agronomy \& Phytopathology Study Groups Meeting, Montreux, Switzerland, Octobre 6-10, 1997, Information Bulletin, p. 138.

Address for correspondence:

René Delon

Seita, Institut du tabac

24100 Bergerac

France 